\title{
Enhanced inhibition of bromate formation in catalytic ozonation of organic pollutants over $\mathrm{Fe}-\mathrm{Al} \mathrm{LDH} / \mathrm{Al}_{2} \mathrm{O}_{3}$
}

\author{
Yulun $\mathrm{Nie}^{\mathrm{a}}$, Nengneng $\mathrm{Li}^{\mathrm{a}, \mathrm{b}}$, Chun $\mathrm{Hu}^{\mathrm{a}, *}$ \\ ${ }^{a}$ Key Laboratory of Drinking Water Science and Technology, Research Center for Eco-Environmental Sciences, Chinese Academy of Sciences, Beijing 100085, China \\ ${ }^{\mathrm{b}}$ Ningxia Great Wall Water Co. Ltd., Yinchuan 750000, China
}

\section{A R T I C L E I N F O}

\section{Article history:}

Received 6 January 2015

Received in revised form 22 July 2015

Accepted 25 July 2015

Available online 26 July 2015

\section{Keywords:}

$\mathrm{Fe}-\mathrm{Al} \mathrm{LDH} / \mathrm{Al}_{2} \mathrm{O}_{3}$

Catalytic ozonation

Organic compound

Surface Fe(II)

$\mathrm{BrO}_{3}{ }^{-}$reduction

\begin{abstract}
A B S T R A C T
Fe-Al layered double hydroxides (Fe-Al LDH, the molar ratio of $\mathrm{Fe}(\mathrm{II})$ to $\mathrm{Fe}(\mathrm{III})$ was about $1: 10$ ) was successfully supported and highly dispersed on mesoporous $\mathrm{Al}_{2} \mathrm{O}_{3}$ based on the X-ray diffraction (XRD) and $\mathrm{X}$-ray photoelectron spectroscopy (XPS) analysis. $\mathrm{Fe}-\mathrm{Al} \mathrm{LDH} / \mathrm{Al}_{2} \mathrm{O}_{3}$ was more efficient in inhibiting $\mathrm{BrO}_{3}^{-}$ formation and removing organic pollutant taking ozonation alone as control. Further investigation indicated that $\mathrm{BrO}_{3}^{-}$reduction by surface $\mathrm{Fe}(\mathrm{II})$ was responsible to the complete inhibition of $\mathrm{BrO}_{3}^{-}$formation. $\mathrm{Fe}(\mathrm{II})$ was reduced from the $\mathrm{Fe}(\mathrm{III})$-intermediates complex via an electron transfer process and the reaction of $\mathrm{Fe}(\mathrm{III})$ and $\mathrm{HO}_{2}^{-} / \mathrm{O}_{2}^{--}$in catalytic ozonation. The amount of surface $\mathrm{Fe}(\mathrm{II})$ in catalytic ozonation of amitrole (AMT), phenazone (PZ) and 2,4-dichlorophenoxyacetic acid (2,4-D) was 0.34, 2.47 and $3.30 \mu \mathrm{mol} / \mathrm{g}$, which proved that most of $\mathrm{Fe}(\mathrm{II})$ was generated from the reaction of ozone and $\mathrm{Fe}-\mathrm{Al}$ $\mathrm{LDH} / \mathrm{Al}_{2} \mathrm{O}_{3}$ since $0.33 \mu \mathrm{mol} / \mathrm{g}$ of $\mathrm{Fe}(\mathrm{II})$ existed within the catalyst. The increase of ozone amount and the formation of $\mathrm{Fe}(\mathrm{III})$-intermediates complex could enhance the $\mathrm{Fe}(\mathrm{II})$ generation, leading to more efficient inhibition of $\mathrm{BrO}_{3}^{-}$formation. Finally, $\mathrm{Fe}-\mathrm{Al} \mathrm{LDH} / \mathrm{Al}_{2} \mathrm{O}_{3}$ still showed effectiveness in the inhibition of $\mathrm{BrO}_{3}^{-}$and $\mathrm{TOC}$ removal for a raw drinking water under the realistic conditions, which could be applied to the $\mathrm{BrO}_{3}^{-}$mineralization in catalytic ozonation of $\mathrm{Br}^{-}$-containing drinking water.
\end{abstract}

(c) 2015 Elsevier B.V. All rights reserved.

\section{Introduction}

The application of ozonation in drinking water treatment is widespread throughout the world to address water quality problems caused by taste, odor, micropollutants, etc. [1]. However, there exists an important scientific challenge: controlling $\mathrm{BrO}_{3}^{-}$formation as a result of the ozonation of $\mathrm{Br}^{-}$-containing water [1]. Hence, it is very important to minimize or eliminate $\mathrm{BrO}_{3}^{-}$in water treatment due to its carcinogenicity and nephrotoxcity [2].

Three approaches could be used to control $\mathrm{BrO}_{3}^{-}$contamination in the water supply: removal of $\mathrm{Br}^{-}$before $\mathrm{BrO}_{3}^{-}$formation via membrane filtration and ion exchange $[3,4]$; control of $\mathrm{BrO}_{3}^{-}$formation during ozonation by lowering solution pH or adding $\mathrm{H}_{2} \mathrm{O}_{2}$ or $\mathrm{NH}_{3}$ [5,6]; and removal of $\mathrm{BrO}_{3}^{-}$after ozonation via adsorption or chemical reduction $[7,8]$. Among these methods, the minimization of $\mathrm{BrO}_{3}^{-}$formation during ozonation appears as the most promising one since the combination with other treatment process is not necessary. Although the $\mathrm{NH}_{3}$ addition and $\mathrm{pH}$ depression could result in bromate reduction of roughly $50 \%$ and may be applicable in treatment plants [9], if source waters have relatively

\footnotetext{
* Corresponding author.

E-mail address: huchun@rcees.ac.cn (C. Hu).
}

high $\mathrm{NH}_{3}$ concentration and alkalinity, the efficiencies of those processes may well be found insufficient [10]. Hence, novel methods are still urgently needed to minimize bromate formation during ozonation.

Recently, there are increasing interests on catalytic ozonation with various catalysts to improve the oxidation efficiency of ozonation [11-13]. Our and other studies have verified that more reactive oxygen species were generated from the interaction of ozone and surface Lewis acid sites of catalysts [14-16]. The organic compounds could be removed more efficiently, while few studies have been conducted to investigate the control of $\mathrm{BrO}_{3}^{-}$formation during the heterogeneous catalytic ozonation $[17,18]$.

In ozonation process, the removal of organic compounds and the oxidation of $\mathrm{Br}^{-}$to $\mathrm{BrO}_{3}^{-}$are competitive reactions in consuming the reactive oxygen species $[9,19]$. $\mathrm{BrO}_{3}^{-}$is also a strong oxidant that can be reduced to $\mathrm{Br}^{-}$in water by reduced iron species $\left(\mathrm{Fe}^{2+}\right.$ or $\mathrm{Fe}^{0}$ ) [8]. Moreover, our and other studies have verified that more $\mathrm{Fe}(\mathrm{II})$ could be generated from the reaction of $\mathrm{Fe}(\mathrm{III})$ and $\mathrm{HO}_{2}^{-} / \mathrm{O}_{2}^{--}$due to the complexation of $\mathrm{Fe}(\mathrm{III})$ with the oxygen functional groups $(-\mathrm{OH}$ and $-\mathrm{COOH})$ of intermediates $[20,21]$. For example, the reaction rate constant of $\mathrm{Fe}(\mathrm{III})$ with $\mathrm{HO}_{2}^{-} / \mathrm{O}_{2}^{--}$was only $1.4 \times 10^{5} \mathrm{M}^{-1} \mathrm{~s}^{-1}$, while it could be greatly enhanced to $2.0 \times 10^{6} \mathrm{M}^{-1} \mathrm{~s}^{-1}$ due to the complexation of $\mathrm{Fe}(\mathrm{III})$ with ligand 
$[22,23]$. Thus, it is necessary to investigate the degradation process of organic compounds with different structure and its influence on the minimization of $\mathrm{BrO}_{3}^{-}$formation in catalytic ozonation.

Recently, $\mathrm{Fe}-\mathrm{Al} \mathrm{LDH}$ has been used to reduce $\mathrm{BrO}_{3}^{-}$in water via an adsorption process [24,25]. In this study, Fe-Al LDH was supported on mesoporous $\gamma-\mathrm{Al}_{2} \mathrm{O}_{3}$ by a hydrothermal hydrolysis process and its performance on catalytic ozonation of refractory organics and $\mathrm{BrO}_{3}^{-}$control was also investigated. Three compounds with different structure were selected to evaluate the influence on $\mathrm{BrO}_{3}^{-}$control during their degradation process. It has been proven that different amount of intermediates was formed in catalytic ozonation of organic compounds and the complexes of Fe(III) with intermediates $(-\mathrm{OH}$ and $-\mathrm{COOH})$ resulted in different amount of surface $\mathrm{Fe}(\mathrm{II})$, leading to different $\mathrm{BrO}_{3}^{-}$reduction rate over $\mathrm{Fe}-\mathrm{Al}$ $\mathrm{LDH} / \mathrm{Al}_{2} \mathrm{O}_{3}$. These findings will facilitate the development of catalytic ozonation for purification of $\mathrm{Br}^{-}$-containing water.

\section{Experimental}

\subsection{Materials and reagents}

Aluminum $i$-propoxide, glucose and $\mathrm{NaOH}$ were purchased from Beijing Chemical Reagents (Beijing, China). $\mathrm{FeCl}_{2} \cdot 4 \mathrm{H}_{2} \mathrm{O}$, $\mathrm{AlCl}_{3} \cdot 6 \mathrm{H}_{2} \mathrm{O}, \mathrm{KBrO}_{3}$ and $\mathrm{KBr}$ were acquired from Yili Company (Beijing, China). 2,4-dichlorophenoxyacetic acid (2,4-D), phenazone (PZ), and amitrole (AMT) were purchased from Acros (Geel, Belgium) and their molecular structures were also provided (Table S1). Raw source water used in this study was obtained from Huanghe River, Zhengzhou, Henan Province, China. All other chemicals were analytical grade and used without further purification. All aqueous solutions were prepared with deionized water.

\subsection{Catalyst preparation}

Mesoporous $\mathrm{Al}_{2} \mathrm{O}_{3}$ was prepared as described previously [14]. Based on the reference [24], $\mathrm{Fe}-\mathrm{Al} \mathrm{LDH}$ was supported on $\mathrm{Al}_{2} \mathrm{O}_{3}$ by co-precipitation method with continuous nitrogen gas bubbling. In a typical procedure, $\mathrm{FeCl}_{2} \cdot 4 \mathrm{H}_{2} \mathrm{O}$ and $\mathrm{AlCl}_{3} \cdot 6 \mathrm{H}_{2} \mathrm{O}(\mathrm{Fe} / \mathrm{Al}$ molar ratio was 1:1) were dissolved in $3 \mathrm{~mL}$ of deionized water and $2 \mathrm{~g} \mathrm{Al}_{2} \mathrm{O}_{3}$ was then added to this solution. After the pH was adjusted to 7.0 slowly using $\mathrm{NaOH}$ solution $(3.0 \mathrm{~mol} / \mathrm{L})$, the resulting suspension was transferred immediately into Teflon tubes and kept at $373 \mathrm{~K}$ for $24 \mathrm{~h}$. The solid product was isolated by centrifuging, washing with deionized water and finally drying overnight at $40{ }^{\circ} \mathrm{C}$ in a vacuum. The obtained $\mathrm{Fe}-\mathrm{Al} \mathrm{LDH} / \mathrm{Al}_{2} \mathrm{O}_{3}$ was stored in tightly capped bottles for further use. For a reference, Fe-Al LDH was also prepared by repeating the same procedure described above except the addition of mesoporous $\mathrm{Al}_{2} \mathrm{O}_{3}$.

\subsection{Characterization}

Powder X-ray diffraction (XRD) of the catalyst was recorded on an XDS-2000 Diffractometer (Scintag, Cupertino, CA) with $\mathrm{Cu} \mathrm{K}_{\alpha}$ radiation $(\lambda=1.54059 \AA)$. The X-ray photoelectron spectroscopy (XPS) data of $\mathrm{Fe}-\mathrm{Al} \mathrm{LDH} / \mathrm{Al}_{2} \mathrm{O}_{3}$ was taken on an AXIS-Ultra instrument from Kratos using monochromatic Al Kradiation (225 W, $15 \mathrm{~mA}, 15 \mathrm{kV}$ ) and low-energy electron flooding for charge compensation. To compensate for surface charge effects, the binding energies were calibrated using the $C_{1 \text { s }}$ hydrocarbon peak at $284.80 \mathrm{eV}$. The zeta potential of catalysts in the $\mathrm{KNO}_{3}$ $\left(1 \times 10^{-3} \mathrm{M}\right)$ solution was measured with a Zetasizer 2000 (Malvern, Worcestershire, UK) with three consistent readings.

\subsection{Procedures and analysis}

A 300-mL three-neck flask was used as a reactor and the reaction temperature was maintained at $20^{\circ} \mathrm{C}$. In a typical experiment, $220 \mathrm{~mL}$ deionized water was placed into the reactor, which was continuously magnetically stirred, and oxygen-ozone gas was bubbled into the reactor to obtain $2.0 \mathrm{mg} / \mathrm{L}$ ozone aqueous solution (the oxygen-ozone gas was stopped when the catalytic ozonation reaction started). Then, aqueous suspensions with the desired amount of catalyst and organic compounds, $\mathrm{Br}^{-}$or $\mathrm{BrO}_{3}^{-}$were added into the reactor, which was sealed and magnetically stirred, with a final total volume of $250 \mathrm{~mL}$. In all experiments, the $\mathrm{pH}$ of the suspensions was not adjusted during the reaction. In general, the initial suspension $\mathrm{pH}$ was about 6 , which remained the same within 0.3 units at the end.

Samples were taken at given time intervals (the residual $\mathrm{O}_{3}$ was liberated by $\mathrm{N}_{2}$ purging) and filtered through a Millipore filter (pore size $0.45 \mu \mathrm{m}$ ) to remove particles. The filtrates were then divided into several parts for respective measurements of total organic carbon (TOC), $\mathrm{BrO}_{3}^{-}$and $\mathrm{Br}^{-}$by TOC analyzer (TOC-VCPH, SHIMADZU) and ICS-2000 ion chromatography (Dionex Corporations, USA). The ozone was generated by a 3S-A5 laboratory ozonizer (Tonglin Technology, China). All of the experiments were repeated three times.

$\mathrm{Fe}(\mathrm{II})$ on the surface of $\mathrm{Fe}-\mathrm{Al} \mathrm{LDH} / \mathrm{Al}_{2} \mathrm{O}_{3}$ was determined using a phenanthroline spectrophotometric method [26]. 1,10-phenanthroline was used as a probe agent for the detection of $\mathrm{Fe}(\mathrm{II})$, and could take up $\mathrm{Fe}(\mathrm{II})$ from the surface of the solid-phase $\mathrm{Fe}-\mathrm{Al} \mathrm{LDH} / \mathrm{Al}_{2} \mathrm{O}_{3}$ via a specific chelating reaction. The samples were prepared as follows: the catalyst dispersions under different conditions were filtered and the resulting solid was resuspended in $10 \mathrm{~mL}$ of deionized water. After the addition of $1.0 \mathrm{~mL}$ of 1,10-phenanthroline solution and reaction for $10 \mathrm{~min}$, the new dispersion was filtered and the filtrates were analyzed by recording the absorbance at $510 \mathrm{~nm}$. As a reference, no Fe(II) was detected in the filtrates from $\mathrm{Fe}-\mathrm{Al} \mathrm{LDH} / \mathrm{Al}_{2} \mathrm{O}_{3}$ dispersions from different reaction conditions. The concentration of ozone dissolved in the aqueous phase was determined with the indigo method [27].

The samples for GC-MS analysis were prepared by the following procedure. The suspensions of $\mathrm{Fe}-\mathrm{Al} \mathrm{LDH} / \mathrm{Al}_{2} \mathrm{O}_{3}$ with different pollutants after reaction with ozone for $15 \mathrm{~min}$ were filtered. The resulting solution and $\mathrm{Fe}-\mathrm{Al} \mathrm{LDH} / \mathrm{Al}_{2} \mathrm{O}_{3}$ particles were evaporated by the freeze-drying method separately. The residues were dissolved with $2.0 \mathrm{ml}$ dichloromethane and the main products on the surface of $\mathrm{Fe}-\mathrm{Al} \mathrm{LDH} / \mathrm{Al}_{2} \mathrm{O}_{3}$ could be extracted by dichloromethane. Then, the suspension was trimethylsilylated with $0.1 \mathrm{ml}$ of hexamethyldisilazane and $0.05 \mathrm{ml}$ of chlorotrimethylsilane at room temperature. The mixture was shaken vigorously for about $60 \mathrm{~s}$ and then allowed to stand for $5 \mathrm{~min}$ at room temperature. Precipitate was separated by filtration prior to chromatographic analysis. GC-MS analysis was carried out on Agilent 6890GC/5973MSD with a DB-5 MS capillary column. The chromatographic conditions were as follows: the initial column temperature was held for $20 \mathrm{~min}$ at $353 \mathrm{~K}$, ramped at $3.5 \mathrm{~K} / \mathrm{min}$ to $553 \mathrm{~K}$.

\section{Results and discussion}

\subsection{Characterization of $\mathrm{Fe}-\mathrm{Al} \mathrm{LDH} / \mathrm{Al}_{2} \mathrm{O}_{3}$}

As shown in Fig. 1, the as-prepared Fe-Al LDH exhibited symmetric reflections of the basal (003) and (006) planes, which were the characterization of typical layered structure of LDH. However, no XRD diffraction peaks of LDH structure were observed in the supported sample, which was presumably due to its low loading 


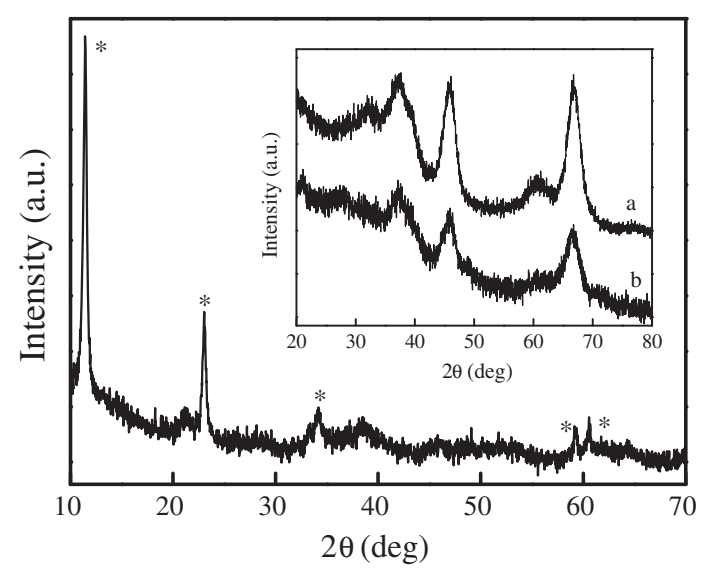

Fig. 1. XRD patterns of as-prepared $\mathrm{Fe}-\mathrm{Al} \mathrm{LDH}$. The inset showed the XRD patterns of (a) $\mathrm{Al}_{2} \mathrm{O}_{3}$, (b) $\mathrm{Fe}-\mathrm{Al} \mathrm{LDH} / \mathrm{Al}_{2} \mathrm{O}_{3}$.

content (10wt\%) and high dispersion on $\mathrm{Al}_{2} \mathrm{O}_{3}$. Therefore, the supported sample was designated $\mathrm{Fe}-\mathrm{Al} \mathrm{LDH} / \mathrm{Al}_{2} \mathrm{O}_{3}$.

The oxidation state of iron on the surface of $\mathrm{Fe}-\mathrm{Al} \mathrm{LDH} / \mathrm{Al}_{2} \mathrm{O}_{3}$ was confirmed by XPS analysis and the results were shown in Fig. 2. The peaks at 709.0 and $711.5 \mathrm{eV}$ for the binding energies of $\mathrm{Fe} 2 \mathrm{p}_{3 / 2}$ were assigned to $\mathrm{Fe}(\mathrm{II})$ and $\mathrm{Fe}(\mathrm{III})$ species, in which the molar ratio of $\mathrm{Fe}(\mathrm{II})$ to $\mathrm{Fe}(\mathrm{III})$ on the surface of $\mathrm{Fe}-\mathrm{Al} \mathrm{LDH} / \mathrm{Al}_{2} \mathrm{O}_{3}$ was about $1: 10$. Fig. 3 presented the zeta potential changes of different samples with the $\mathrm{pH}$ of the solution. The upward shift of PZC (point of zero charge) from 6.3 for $\mathrm{Al}_{2} \mathrm{O}_{3}$ used as support to 9.3 was observed after the loading of $\mathrm{Fe}-\mathrm{Al} \mathrm{LDH}$. Hence, the positively charged surface should favor the $\mathrm{BrO}_{3}^{-}$adsorption on the surface of $\mathrm{Fe}-\mathrm{Al} \mathrm{LDH} / \mathrm{Al}_{2} \mathrm{O}_{3}$ at neutral $\mathrm{pH}$ values. Besides, the stronger Lewis acid sites within the catalyst should cause the more chemisorbed water enhancing the interaction with ozone, resulting in higher catalytic reactivity [14].

\subsection{Catalytic ozonation of organic pollutant and $\mathrm{BrO}_{3}^{-}$formation inhibition over $\mathrm{Fe}-\mathrm{Al} \mathrm{LDH} / \mathrm{Al}_{2} \mathrm{O}_{3}$}

Fig. 4 compared the TOC removal of 2,4-D in ozonation and catalytic ozonation over $\mathrm{Fe}-\mathrm{Al} \mathrm{LDH} / \mathrm{Al}_{2} \mathrm{O}_{3}$. Obviously, the TOC removal efficiency in catalytic ozonation was much higher than that in ozonation alone. About $82 \%$ of TOC was removed under the latter condition at a reaction time of $60 \mathrm{~min}$, while only $28 \%$ of TOC was removed under the former condition. Fig. S1 depicted the effect of tert-butanol (a strong $\mathrm{OH}$ radical scavenger) on 2,4-D

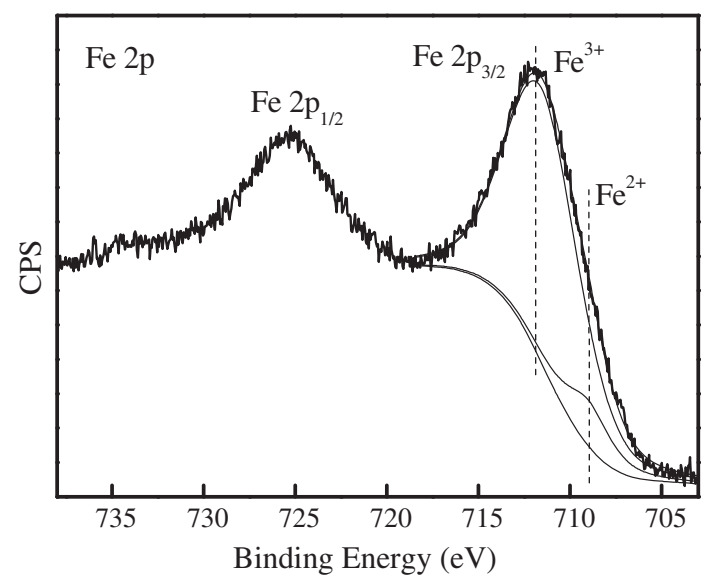

Fig. 2. XPS spectrum of $\mathrm{Fe} 2 \mathrm{p}$ in $\mathrm{Fe}-\mathrm{Al} \mathrm{LDH} / \mathrm{Al}_{2} \mathrm{O}_{3}$.

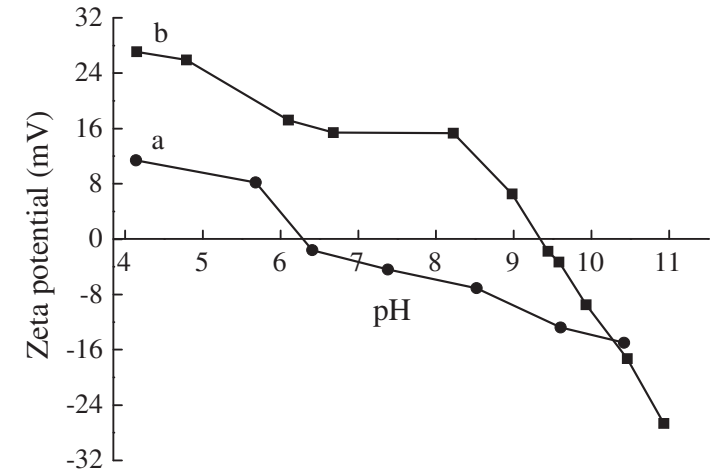

Fig. 3. Plot of the zeta potential as a function of $\mathrm{pH}$ for different suspensions in the presence of $\mathrm{KNO}_{3}\left(1 \times 10^{-3} \mathrm{~mol} / \mathrm{L}\right)$ : (a) $\mathrm{Al}_{2} \mathrm{O}_{3}$, (b) $\mathrm{Fe}-\mathrm{Al} \mathrm{LDH} / \mathrm{Al}_{2} \mathrm{O}_{3}$.

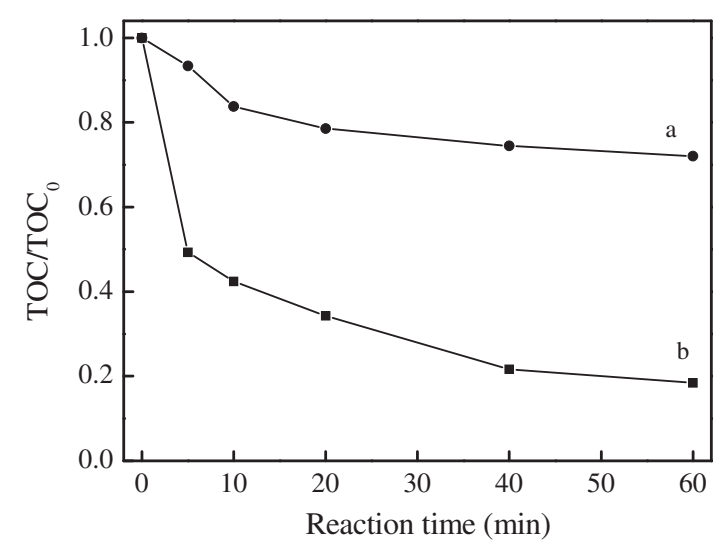

Fig. 4. TOC removal efficiency of 2,4-D (a) in ozonation and (b) catalytic ozonation over $\mathrm{Fe}-\mathrm{Al} \mathrm{LDH} / \mathrm{Al}_{2} \mathrm{O}_{3}$ (initial $\mathrm{pH} 6.0$, catalyst concentration $0.25 \mathrm{~g} / \mathrm{L}$, initial concentration of ozone in solution $2.0 \mathrm{mg} / \mathrm{L}, 2,4-\mathrm{D}$ concentration $45.2 \mu \mathrm{mol} / \mathrm{L}$ ).

degradation in ozonation and catalytic ozonation over $\mathrm{Fe}-\mathrm{Al}$ $\mathrm{LDH} / \mathrm{Al}_{2} \mathrm{O}_{3}$. Obviously, 2,4-D removal efficiency was greatly inhibited from $98 \%$ to $70 \%$ and from $78 \%$ to $65 \%$ via the addition of tert-butanol in ozonation and catalytic ozonation, respectively. Tert-butanol exhibited a more negative effect on the 2,4-D degradation in catalytic ozonation over $\mathrm{Fe}-\mathrm{Al} \mathrm{LDH} / \mathrm{Al}_{2} \mathrm{O}_{3}$ than that in ozonation process. It indicated that $\cdot \mathrm{OH}$ was present and involved in efficiently catalytic ozonation of 2,4-D and $\mathrm{Fe}-\mathrm{Al} \mathrm{LDH} / \mathrm{Al}_{2} \mathrm{O}_{3}$ accelerated more ozone transformation into $\cdot \mathrm{OH}$ radicals.

The dissolved $\mathrm{Fe}^{3+}$ and $\mathrm{Al}^{3+}$ in solution after reaction were measured using ICP-AES to confirm the degree of dissolution of Fe and Al from catalyst. As shown in Table $\mathrm{S} 2$, there was no $\mathrm{Fe}^{3+}$ and $0.18 \mathrm{mg} / \mathrm{L} \mathrm{Al}^{3+}$ in solution for $\mathrm{Fe}-\mathrm{Al} \mathrm{LDH} / \mathrm{Al}_{2} \mathrm{O}_{3}$, while the concentration of leached $\mathrm{Fe}^{3+}$ and $\mathrm{Al}^{3+}$ from $\mathrm{Fe}-\mathrm{Al} \mathrm{LDH}$ was 5.58 and $6.38 \mathrm{mg} / \mathrm{L}$. Especially, $\mathrm{Fe}-\mathrm{Al} \mathrm{LDH} / \mathrm{Al}_{2} \mathrm{O}_{3}$ could be reused for at least six cycles and exhibited no significant loss of activity in Fig. S2. It indicated that $\mathrm{Fe}-\mathrm{Al} \mathrm{LDH} / \mathrm{Al}_{2} \mathrm{O}_{3}$ was an effective and stable catalyst for catalytic ozonation. Moreover, the ozonation by-product, $\mathrm{BrO}_{3}^{-}$ was also efficiently controlled in catalytic ozonation process. As shown in Fig. 5, the $\mathrm{BrO}_{3}^{-}$concentration increased quickly in ozonation and reached $20 \mu \mathrm{g} / \mathrm{L}$, which is considerably above the allowable limit of $10 \mu \mathrm{g} / \mathrm{L}$. In contrast, almost no $\mathrm{BrO}_{3}^{-}$was detected in $\mathrm{Fe}-\mathrm{Al} \mathrm{LDH} / \mathrm{Al}_{2} \mathrm{O}_{3}-\mathrm{O}_{3}$ system, indicating that the $\mathrm{BrO}_{3}^{-}$formation was completely inhibited. Moreover, even when the $\mathrm{Br}^{-}$initial concentration and ozone dose increased, the $\mathrm{BrO}_{3}^{-}$concentration after $60 \mathrm{~min}$ reaction is still below $10 \mu \mathrm{g} / \mathrm{L}$ in catalytic ozonation (Fig. S3). 


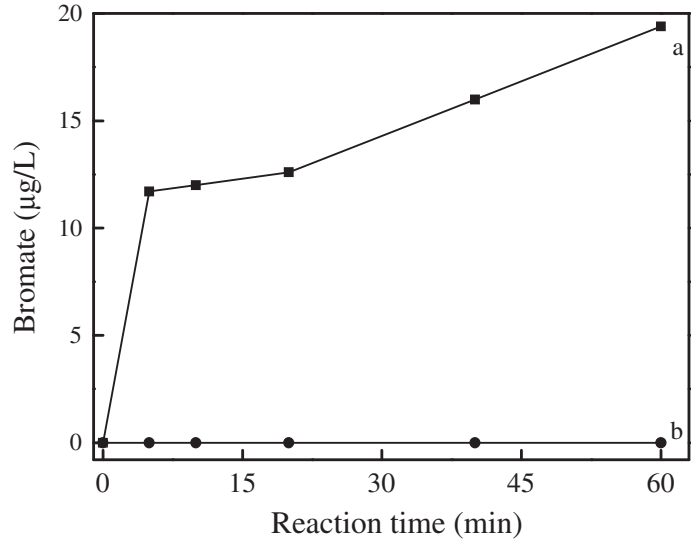

Fig. 5. $\mathrm{BrO}_{3}^{-}$formation in (a) ozonation and (b) catalytic ozonation over $\mathrm{Fe}-\mathrm{Al} \mathrm{LDH} /$ $\mathrm{Al}_{2} \mathrm{O}_{3}$ (initial pH 6.0, catalyst concentration $0.25 \mathrm{~g} / \mathrm{L}$, initial concentration of ozone in solution $2.0 \mathrm{mg} / \mathrm{L}, 2,4-\mathrm{D}$ concentration $45.2 \mu \mathrm{mol} / \mathrm{L}$, initial $\mathrm{Br}^{-}$concentration $1.25 \mu \mathrm{mol} / \mathrm{L})$.

\subsection{Mechanism for $\mathrm{BrO}_{3}^{-}$inhibition over $\mathrm{Fe}-\mathrm{Al} \mathrm{LDH} / \mathrm{Al}_{2} \mathrm{O}_{3}$}

As shown in Fig. 6, about $45 \%$ of $\mathrm{BrO}_{3}^{-}(0.33 \mu \mathrm{mol} / \mathrm{L})$ was adsorbed on $\mathrm{Fe}-\mathrm{Al} \mathrm{LDH} / \mathrm{Al}_{2} \mathrm{O}_{3}$ and $0.14 \mu \mathrm{mol} / \mathrm{L} \mathrm{Br}^{-}$was generated only in the presence of $\mathrm{PZ}$ and $\mathrm{BrO}_{3}^{-}$, which could be attributed to the $\mathrm{BrO}_{3}^{-}$reduction by $\mathrm{Fe}(\mathrm{II})$ species formed during $\mathrm{Fe}-\mathrm{Al}$ $\mathrm{LDH} / \mathrm{Al}_{2} \mathrm{O}_{3}$ preparation based on XPS analysis [28]. However, 82\% of $\mathrm{BrO}_{3}^{-}(0.64 \mu \mathrm{mol} / \mathrm{L})$ was converted into $\mathrm{Br}^{-}(0.40 \mu \mathrm{mol} / \mathrm{L})$ in the $\mathrm{Fe}-\mathrm{Al} \mathrm{LDH} / \mathrm{Al}_{2} \mathrm{O}_{3}-\mathrm{O}_{3}$ system during the $\mathrm{PZ}$ degradation process.
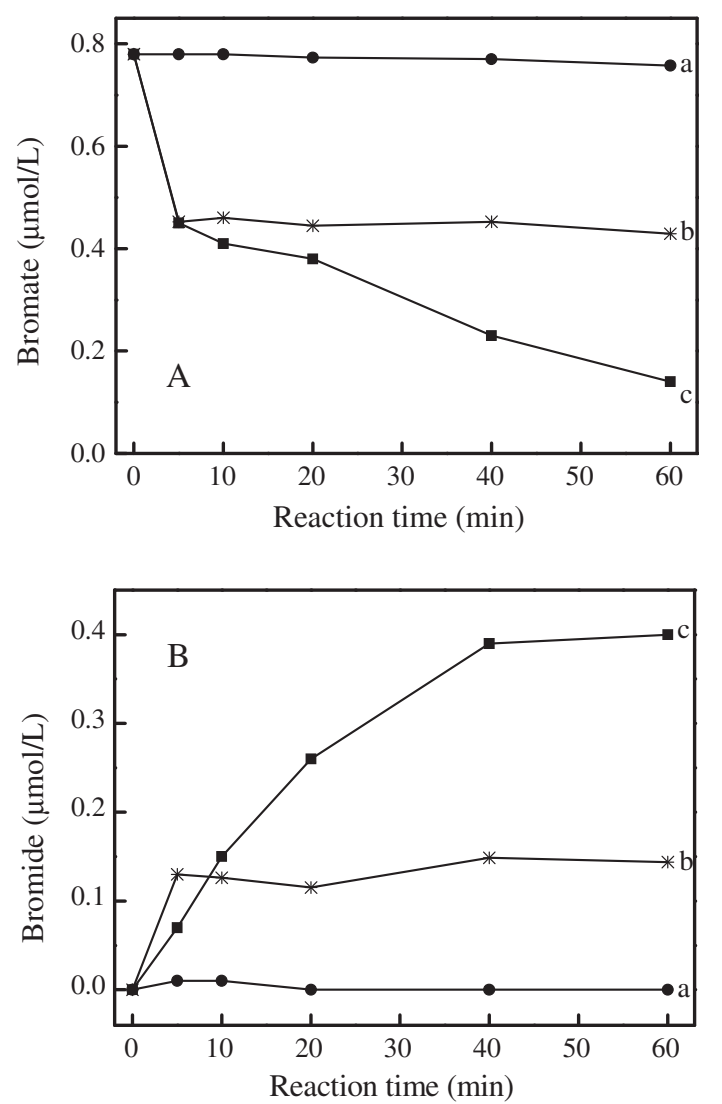

Fig. 6. $\mathrm{Br}^{-}$formation (B) as a result of $\mathrm{BrO}_{3}^{-}$reduction (A) in (a) ozonation, (b) $\mathrm{BrO}_{3}^{-}$ adsorption and (c) catalytic ozonation over $\mathrm{Fe}-\mathrm{Al} \mathrm{LDH} / \mathrm{Al}_{2} \mathrm{O}_{3}$ (initial $\mathrm{pH}$ 6.0, catalyst concentration $0.25 \mathrm{~g} / \mathrm{L}$, initial concentration of ozone in solution $2.0 \mathrm{mg} / \mathrm{L}$, initial $\mathrm{BrO}_{3}^{-}$concentration $0.78 \mu \mathrm{mol} / \mathrm{L}, \mathrm{PZ}$ concentration $45.2 \mu \mathrm{mol} / \mathrm{L}$ ).
The reduction efficiency of $\mathrm{BrO}_{3}^{-}$increased with the increase of ozone dose and $\mathrm{BrO}_{3}^{-}$initial concentration (Figs. S4 and S5). In contrast, neither $\mathrm{BrO}_{3}^{-}$reduction nor $\mathrm{Br}^{-}$formation was observed in $\mathrm{PZ}^{-} \mathrm{O}_{3}$ system. Moreover, $\mathrm{BrO}_{3}^{-}$reduction and $\mathrm{TOC}$ removal of 2,4-D solution were almost completely inhibited with the addition of phosphate into $\mathrm{Fe}-\mathrm{Al} \mathrm{LDH} / \mathrm{Al}_{2} \mathrm{O}_{3}-\mathrm{O}_{3}$ system (Fig. 7). It was because that the adsorption of $\mathrm{BrO}_{3}^{-}$and the interaction of $\mathrm{O}_{3}$ with $\mathrm{Fe}-\mathrm{Al} \mathrm{LDH} / \mathrm{Al}_{2} \mathrm{O}_{3}$ were both greatly inhibited, since phosphate could cause permanent blockage of the catalysts active surface sites and decrease their catalytic activity via replacing the surface hydroxyl group and forming complex with $\mathrm{Fe}(\mathrm{III})$ within the catalyst [29-31]. The above results confirmed that $\mathrm{BrO}_{3}^{-}$reduction happened on the surface of $\mathrm{Fe}-\mathrm{Al} \mathrm{LDH} / \mathrm{Al}_{2} \mathrm{O}_{3}$.

To confirm the roles of $\mathrm{Fe}(\mathrm{II})$ and the complexes of iron with organics for the $\mathrm{BrO}_{3}^{-}$reduction to $\mathrm{Br}^{-}$, the removal of $\mathrm{BrO}_{3}^{-}$in the presence of $\mathrm{Fe}(\mathrm{II}), \mathrm{Fe}(\mathrm{III})$ and/or HA without ozone was further investigated. As shown in Fig. S6, only $22.4 \%$ of $\mathrm{BrO}_{3}^{-}$was reduced to $\mathrm{Br}^{-}$by $\mathrm{Fe}(\mathrm{II})$ alone (curve a) at $14 \mathrm{~h}$ due to the rapid oxidation of $\mathrm{Fe}(\mathrm{II})$ by oxygen in water, while the reduction rate was significantly enhanced and $81.6 \%$ of $\mathrm{BrO}_{3}^{-}$was reduced (curve b) in the presence of $\mathrm{HA}$ and $\mathrm{Fe}(\mathrm{II})$. While no significant $\mathrm{BrO}_{3}^{-}$reduction was observed in $\mathrm{Fe}(\mathrm{III})$ and $\mathrm{HA}$ containing solution (curve c) because the $\mathrm{Fe}(\mathrm{II})$ formation via an electron transfer process within the complex of $\mathrm{HA}-\mathrm{Fe}(\mathrm{III})$ is a very slow process (about several hundred hours) [28]. The results indicated that $\mathrm{BrO}_{3}^{-}$was reduced by $\mathrm{Fe}(\mathrm{II})[24,25]$ and enhanced by the complexes of iron and HA. Fig. 8 showed the $\mathrm{BrO}_{3}^{-}$reduction was significantly promoted in catalytic ozonation of different organic pollutant with the order of $\mathrm{AMT}<\mathrm{PZ}<2,4-\mathrm{D}$. The amount of surface $\mathrm{Fe}(\mathrm{II})$ on $\mathrm{Fe}-\mathrm{Al}$ $\mathrm{LDH} / \mathrm{Al}_{2} \mathrm{O}_{3}$ in catalytic ozonation of different organic pollutant was also determined and the results were shown in Table 1. Obviously, $0.33 \mu \mathrm{mol} / \mathrm{g}$ of $\mathrm{Fe}(\mathrm{II})$ was detected on the surface of $\mathrm{Fe}-\mathrm{Al} \mathrm{LDH} / \mathrm{Al}_{2} \mathrm{O}_{3}$ in aqueous suspension, which was attributed to the formed $\mathrm{Fe}(\mathrm{II})$ during the catalyst preparation (XPS analysis in Fig. 2). The amount of surface Fe(II) increased greatly during the catalytic ozonation of different organic pollutants and the amount of surface Fe(II) was $0.34,2.47$ and $3.30 \mu \mathrm{mol} / \mathrm{g}$ for AMT, PZ and 2,4-D respectively, which agreed well with the results of $\mathrm{BrO}_{3}^{-}$ reduction. Fig. S7 further depicted the bromine mass balance during bromate reduction under different conditions. The results indicated that the structure of organic compound has a positive effect on the catalytic reduction of $\mathrm{BrO}_{3}^{-}$and the surface $\mathrm{Fe}(\mathrm{II})$ for $\mathrm{BrO}_{3}^{-}$ reduction mainly came from the generation of $\mathrm{Fe}(\mathrm{II})$ in catalytic ozonation over $\mathrm{Fe}-\mathrm{Al} \mathrm{LDH} / \mathrm{Al}_{2} \mathrm{O}_{3}$. Moreover, organic compounds

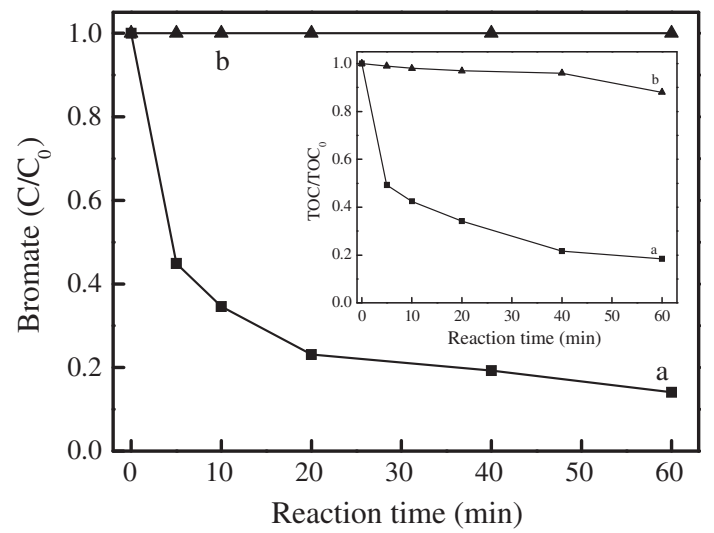

Fig. 7. Effect of $\mathrm{PO}_{4}^{3-}(5 \mathrm{mmol} / \mathrm{L})$ on $\mathrm{BrO}_{3}^{-}$reduction and the $\mathrm{TOC}$ removal of 2,4-D (inset) in catalytic ozonation over $\mathrm{Fe}-\mathrm{Al} \mathrm{LDH} / \mathrm{Al}_{2} \mathrm{O}_{3}$ : (a) without $\mathrm{PO}_{4}^{3-}$, (b) with $\mathrm{PO}_{4}^{3-}$ (initial pH 6.0, catalyst concentration $0.25 \mathrm{~g} / \mathrm{L}$, initial concentration of ozone $2.0 \mathrm{mg} /$ $\mathrm{L}$, initial $\mathrm{BrO}_{3}^{-}$concentration $0.78 \mu \mathrm{mol} / \mathrm{L}$, initial 2,4-D concentration $45.2 \mu \mathrm{mol} / \mathrm{L}$ ). 

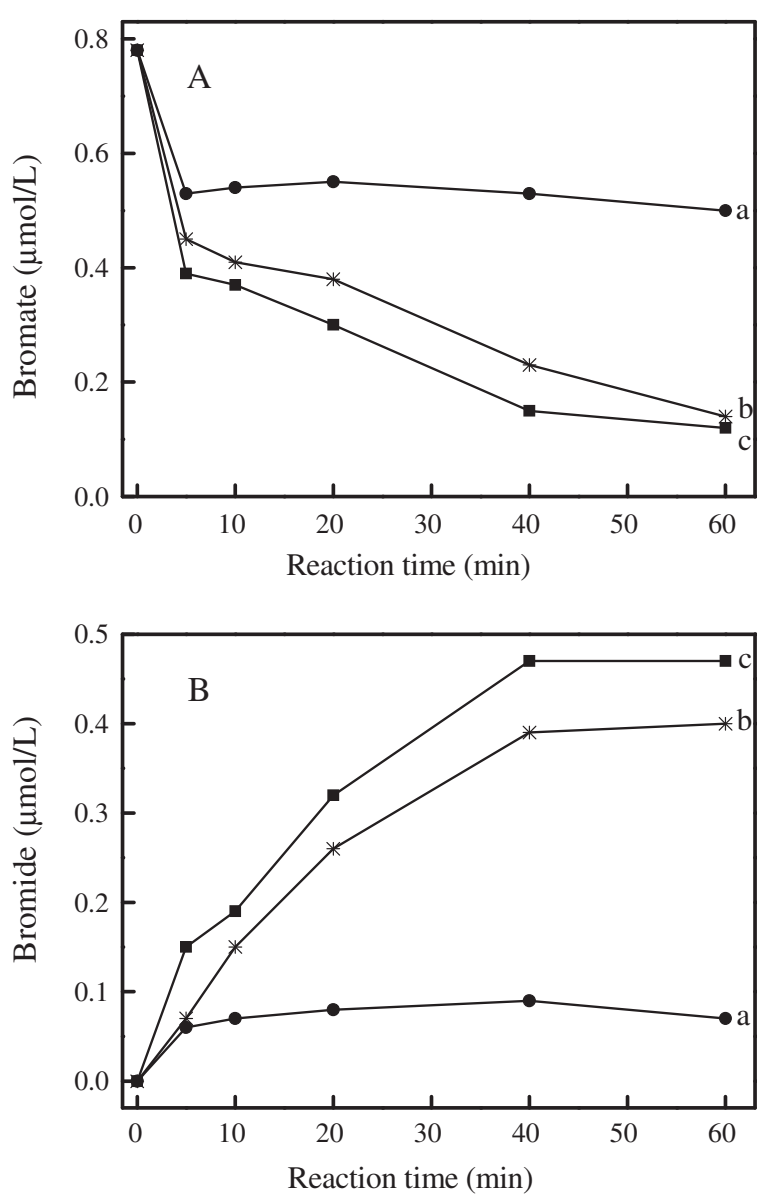

Fig. 8. Effect of organic pollutant on $\mathrm{BrO}_{3}^{-}$reduction in catalytic ozonation over $\mathrm{Fe}-$ $\mathrm{Al} \mathrm{LDH} / \mathrm{Al}_{2} \mathrm{O}_{3}$ : (a) AMT, (b) PZ, (c) 2,4-D (initial pH 6.0, catalyst concentration $0.25 \mathrm{~g} /$ $\mathrm{L}$, initial concentration of ozone in solution $2.0 \mathrm{mg} / \mathrm{L}$, initial $\mathrm{BrO}_{3}^{-}$concentration $0.78 \mu \mathrm{mol} / \mathrm{L}$, initial pollutants concentration $45.2 \mu \mathrm{mol} / \mathrm{L}$ ).

and their catalytic ozonation byproducts had a positive effect on the enhancement of $\mathrm{Fe}(\mathrm{II})$ generation.

Hence, the intermediates generated in catalytic ozonation of 2,4-D, PZ and AMT over Fe-Al $\mathrm{LDH} / \mathrm{Al}_{2} \mathrm{O}_{3}$ for $15 \mathrm{~min}$ were monitored by GC-MS analysis (all the identified compounds were unequivocally identified using the NIST98 library database with fit values higher than 90\%). As shown in Tables S3-S6, for PZ and 2,4-D, the detected product in solution was mainly small molecular organic compound, such as glycerol, indicating their structure was completely destroyed. While organic acid that containing carboxylic group was found on the surface of $\mathrm{Fe}-\mathrm{Al} \mathrm{LDH} / \mathrm{Al}_{2} \mathrm{O}_{3}$. In contrast, no product for AMT was detected either in solution or on the surface of catalyst. According to the previous work [16,32], adsorbed $\mathrm{HO}_{2}^{--} / \mathrm{O}_{2}^{--}$could be generated from the interaction of $\mathrm{O}_{3}$ and $\mathrm{Fe}-\mathrm{Al} \mathrm{LDH} / \mathrm{Al}_{2} \mathrm{O}_{3}$. The reaction rate constant of $\mathrm{Fe}(\mathrm{III})$ with $\mathrm{HO}_{2}^{-} / \mathrm{O}_{2}^{--}$was $1.4 \times 10^{5} \mathrm{M}^{-1} \mathrm{~s}^{-1}$ [22], while the rate constant could be increased ten times to $2.0 \times 10^{6} \mathrm{M}^{-1} \mathrm{~s}^{-1}$ since the complexation of $\mathrm{Fe}(\mathrm{III})$ with ligands can decrease the $\mathrm{Fe}(\mathrm{III}) / \mathrm{Fe}(\mathrm{II})$ redox potential $[20,23]$. Clearly, the enhancement of surface Fe(II) formation could be attributed to the complexation of $\mathrm{Fe}(\mathrm{III})$ by oxygen functional

Table 1

The amount of surface $\mathrm{Fe}(\mathrm{II})$ in catalytic ozonation of different organic pollutant over $\mathrm{Fe}-\mathrm{Al} \mathrm{LDH} / \mathrm{Al}_{2} \mathrm{O}_{3}$.

\begin{tabular}{lllll}
\hline Pollutant & Control & AMT & PZ & $2,4-\mathrm{D}$ \\
\hline $\mathrm{Fe}(\mathrm{II})(\mu \mathrm{mol} / \mathrm{g})$ & 0.33 & 0.34 & 2.47 & 3.30 \\
\hline
\end{tabular}

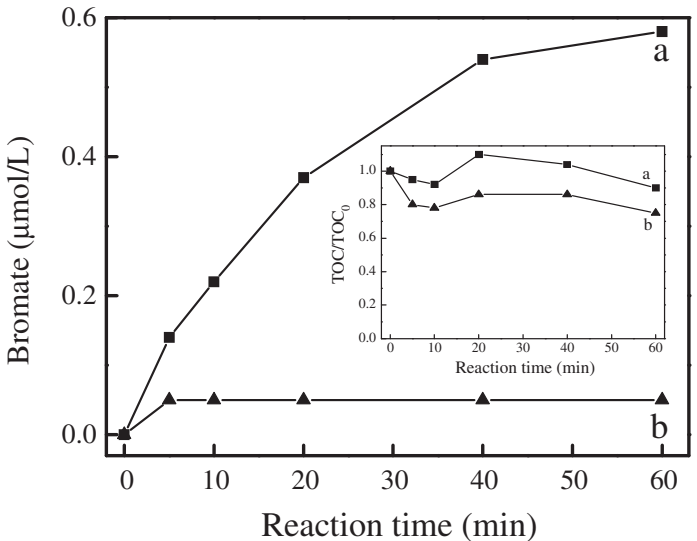

Fig. 9. $\mathrm{BrO}_{3}^{-}$formation and TOC removal (inset) in (a) ozonation and (b) catalytic ozonation over $\mathrm{Fe}-\mathrm{Al} \mathrm{LDH} / \mathrm{Al}_{2} \mathrm{O}_{3}$ treatment of $\mathrm{Br}^{-}$-containing raw drinking water (initial pH 8.0, catalyst concentration $0.25 \mathrm{~g} / \mathrm{L}$, initial concentration of ozone is solution $2.0 \mathrm{mg} / \mathrm{L}$ ).

group of the intermediates in ozonation of different pollutants. It resulted in different $\mathrm{BrO}_{3}^{-}$reduction rate in catalytic ozonation of different pollutant over $\mathrm{Fe}-\mathrm{Al} \mathrm{LDH} / \mathrm{Al}_{2} \mathrm{O}_{3}$. The results indicated that the reduction of adsorbed $\mathrm{BrO}_{3}^{-}$to $\mathrm{Br}^{-}$was proven to be responsible for the $\mathrm{BrO}_{3}^{-}$formation inhibition.

\subsection{Performance of $\mathrm{Fe}-\mathrm{Al} \mathrm{LDH} / \mathrm{Al}_{2} \mathrm{O}_{3}$ for $\mathrm{BrO}_{3}^{-}$inhibition in realistic conditions}

The performance of $\mathrm{Fe}-\mathrm{Al} \mathrm{LDH} / \mathrm{Al}_{2} \mathrm{O}_{3}$ was further evaluated by the treatment of $\mathrm{Br}^{-}$-containing raw drinking water via catalytic ozonation. In the raw water (Table S7), the concentration of TOC and $\mathrm{Br}^{-}$was $3.6 \mathrm{mg} / \mathrm{L}$ and $1.07 \mu \mathrm{mol} / \mathrm{L}$, and the alkalinity was $190 \mathrm{mg} / \mathrm{L}\left(\mathrm{CaCO}_{3}\right)$. As shown in Fig. 9, the $\mathrm{BrO}_{3}^{-}$concentration increased greatly with the reaction time $(0.6 \mu \mathrm{mol} / \mathrm{L}$ at $60 \mathrm{~min})$ and almost no TOC was removed in ozonation. While the $\mathrm{BrO}_{3}^{-}$formation was significantly inhibited in the presence of $\mathrm{Fe}-\mathrm{Al}$ $\mathrm{LDH} / \mathrm{Al}_{2} \mathrm{O}_{3}$ and $25 \%$ of TOC could be removed in the above catalytic ozonation process. These findings may be applied to the minimization of $\mathrm{BrO}_{3}^{-}$formation in catalytic ozonation of $\mathrm{Br}^{-}$-containing raw drinking water.

\section{Conclusions}

$\mathrm{Fe}-\mathrm{Al} \mathrm{LDH} / \mathrm{Al}_{2} \mathrm{O}_{3}$ was proven to be an effective and stable ozonation catalyst. $\mathrm{BrO}_{3}^{-}$formation could also be efficiently inhibited via surface reduction, especially in catalytic ozonation of organic pollutant with this order AMT $<\mathrm{PZ}<2,4-\mathrm{D}$. Surface Fe(II) was proven to be the reactive species for $\mathrm{BrO}_{3}^{-}$reduction and its generation could be greatly enhanced by the $\mathrm{Fe}(\mathrm{III})$-intermediates complex via an electron transfer process and the reaction of $\mathrm{Fe}(\mathrm{III})$ and $\mathrm{HO}_{2}^{-} / \mathrm{O}_{2}^{--}$in catalytic ozonation. Hence, different amount of oxygen functional group generated in catalytic ozonation of organic pollutant would result in different $\mathrm{BrO}_{3}^{-}$reduction rate over $\mathrm{Fe}-\mathrm{Al} \mathrm{LDH} / \mathrm{Al}_{2} \mathrm{O}_{3}$. $\mathrm{Fe}-\mathrm{Al} \mathrm{LDH} / \mathrm{Al}_{2} \mathrm{O}_{3}$ still showed effectiveness for the inhibition of $\mathrm{BrO}_{3}^{-}$formation and $\mathrm{TOC}$ removal for a $\mathrm{Br}^{-}$-containing raw drinking water under the realistic conditions.

\section{Acknowledgement}

This work was supported by the National Natural Science Foundation of China (Nos. 51278527, 51138009, 51221892 and 21125731) and 863 project (No. 2012AA062606). 


\section{Appendix A. Supplementary material}

Supplementary data associated with this article can be found, in the online version, at http://dx.doi.org/10.1016/j.seppur.2015.07. 057.

\section{References}

[1] R.P. Schwarzenbach, B.I. Escher, K. Fenner, T.B. Hofstetter, C.A. Johnson, U. von Gunten, B. Wehrli, The challenge of micropollutants in aquatic systems, Science 313 (2006) 1072-1077.

[2] WHO, Guidelines for Drinking-water Quality, third ed., vol. 1, World Health Organization, Geneva, 2006.

[3] S. Chellam, Effects of nanofiltration on trihalomethane and haloacetic acid precursor removal and speciation in waters containing low concentrations of bromide ion, Environ. Sci. Technol. 34 (2000) 1813-1820.

[4] N.I. Chubar, V.F. Samanidou, V.S. Kouts, G.G. Gallios, V.A. Kanibolotsky, V.V. Strelko, I.Z. Zhuravlev, Adsorption of fluoride, chloride, bromide, and bromate ions on a novel ion exchanger, J. Colloid Interface Sci. 291 (2005) 67-74.

[5] U. von Gunten, Y. Oliveras, Advanced oxidation of bromide-containing waters: bromate formation mechanisms, Environ. Sci. Technol. 32 (1998) 63-70.

[6] R. Hofmann, R.C. Andrews, Impact of $\mathrm{H}_{2} \mathrm{O}_{2}$ and (bi)carbonate alkalinity on ammonia's inhibition of bromate formation, Water Res. 40 (2006) 3343-3348.

[7] W.F. Chen, Z.Y. Zhang, Q. Li, H.Y. Wang, Adsorption of bromate and competition from oxyanions on cationic surfactant-modified granular activated carbon (GAC), Chem. Eng. J. 203 (2012) 319-325.

[8] N. Kishimoto, N. Matsuda, Bromate ion removal by electrochemical reduction using an activated carbon felt electrode, Environ. Sci. Technol. 43 (2009) 20542059.

[9] U. Pinkernell, U. von Gunten, Bromate minimization during ozonation: mechanistic considerations, Environ. Sci. Technol. 35 (2001) 2525-2531.

[10] M.O. Buffle, S. Galli, U. von Gunten, Enhanced bromate control during ozonation: the chlorine-ammonia process, Environ. Sci. Technol. 38 (2004) 5187-5195.

[11] S.T. Xing, C. Hu, J.H. Qu, H. He, M. Yang, Characterization and reactivity of $\mathrm{MnO}_{\mathrm{x}}$ supported on mesoporous zirconia for herbicide 2,4-D mineralization with ozone, Environ. Sci. Technol. 42 (2008) 3363-3368.

[12] L. Yang, C. Hu, Y.L. Nie, J.H. Qu, Catalytic ozonation of selected pharmaceuticals over mesoporous alumina-supported manganese oxide, Environ. Sci. Technol. 43 (2009) 2525-2529.

[13] H. Park, Y. Kim, B. An, H. Choi, Characterization of natural organic matter treated by iron oxide nanoparticle incorporated ceramic membrane-ozonation process, Water Res. 46 (2012) 5861-5870.

[14] L. Yang, C. Hu, Y.L. Nie, J.H. Qu, Surface acidity and reactivity of $\beta-\mathrm{FeOOH} / \mathrm{Al}_{2} \mathrm{O}_{3}$ for pharmaceuticals degradation with ozone: in situ ATR-FTIR studies, Appl. Catal. B Environ. 97 (2010) 340-346.

[15] L. Zhao, Z. Sun, J. Ma, H.L. Liu, Novel relationship between hydroxyl radical initiation and surface group of ceramic honeycomb supported metals for the catalytic ozonation of nitrobenzene in aqueous solution, Environ. Sci. Technol. 43 (2009) 4157-4163.
[16] M. Ernst, F. Lurot, J.C. Schrotter, Catalytic ozonation of refractory organic model compounds in aqueous solution by aluminum oxide, Appl. Catal. B Environ. 47 (2004) 15-25.

[17] T. Zhang, W. Chen, J. Ma, Z.M. Qiang, Minimizing bromate formation with cerium dioxide during ozonation of bromide-containing water, Water Res. 42 (2008) 3651-3658.

[18] T. Zhang, P. Hou, Z.M. Qiang, X.W. Lu, Q.H. Wang, Reducing bromate formation with $\mathrm{H}^{+}$-form high silica zeolites during ozonation of bromide-containing water: effectiveness and mechanisms, Chemosphere 82 (2011) 608-612.

[19] Y. Lee, D. Gerrity, M. Lee, A.E. Bogeat, E. Salhi, S. Gamage, R.A. Trenholm, E.C. Wert, S.A. Snyder, U. von Gunten, Prediction of micropollutant elimination during ozonation of municipal wastewater effluents: use of kinetic and water specific information, Environ. Sci. Technol. 47 (2013) 5872-5881.

[20] T.J. Strathmann, A.T. Stone, Reduction of oxamyl and related pesticides by Fe ${ }^{\text {II. }}$ : influence of organic ligands and natural organic matter, Environ. Sci. Technol. 36 (2002) 5172-5183.

[21] Y.L. Nie, C. Hu, N.N. Li, L. Yang, J.H. Qu, Inhibition of bromate formation by surface reduction in catalytic ozonation of organic pollutants over - $\mathrm{FeOOH} /$ Al203, Appl. Catal. B Environ. 147 (2014) 287-292.

[22] X.F. Xue, K. Hanna, C. Despas, F. Wu, N.S. Deng, Effect of chelating agent on the oxidation rate of PCP in the magnetite $/ \mathrm{H}_{2} \mathrm{O}_{2}$ system at neutral $\mathrm{pH}, \mathrm{J}$. Mol. Catal. A: Chem. 311 (2009) 29-35.

[23] B.G. Kwon, E. Kim, J.H. Lee, Pentachlorophenol decomposition by electron beam process enhanced in the presence of Fe(III)-EDTA, Chemosphere 74 (2009) 1335-1339.

[24] R. Chitrakar, Y. Makita, A. Sonoda, T. Hirotsu, Fe-Al layered double hydroxides in bromate reduction: synthesis and reactivity, J. Colloid Interface Sci. 354 (2011) 798-803.

[25] Y. Zhong, Q. Yang, K. Luo, X.Q. Wu, X.M. Li, Y. Liu, W.W. Tang, G.M. Zeng, B. Peng, $\mathrm{Fe}(\mathrm{II})-\mathrm{Al}(\mathrm{III})$ layered double hydroxides prepared by ultrasound-assisted co-precipitation method for the reduction of bromate, J. Hazard. Mater. 250251 (2013) 345-353.

[26] J. Wu, H. Zhang, J.J. Qiu, Degradation of acid orange 7 in aqueous solution by a novel electro/ $\mathrm{Fe}^{2+} /$ peroxydisulfate process, J. Hazard. Mater. 215-216 (2012) $138-145$.

[27] H. Bader, J. Hoigné, Determination of ozone in water by the indigo method, Water Res. 15 (1980) 449-456.

[28] L. Xie, C. Shang, Q. Zhou, Effect of Fe(III) on the bromate reduction by humic substances in aqueous solution, J. Environ. Sci. 20 (2008) 257-261.

[29] M.I. Tejedor-Tejedor, M.A. Anderson-Langmuir, "In situ” ATR-Fourier transform infrared studies of the goethite $(\alpha$-FeOOH)-aqueous solution interface, Langmuir 2 (1986) 203-210.

[30] M.H. Sui, L. Sheng, K.X. Lu, F. Tian, FeOOH catalytic ozonation of oxalic acid and the effect of phosphate binding on its catalytic activity, Appl. Catal. B Environ. 96 (2010) 94-100.

[31] B. Kasprzyk-Horderna, M. Ziółekb, J. Nawrockia, Catalytic ozonation and methods of enhancing molecular ozone reactions in water treatment, Appl. Catal. B Environ. 46 (2003) 639-669.

[32] J. Staehelin, J. Hoigne, Decomposition of ozone in water: rate of initiation by hydroxide ions and hydrogen peroxide, Environ. Sci. Technol. 16 (1982) 676681. 